BIAtOSTOCKIE

TEKI

HISTORYCZNE

TOM 15/2017

ISSN 1425-1930

\section{Katarzyna Grabowska}

DOI: $10.15290 /$ bth.2017.15.13

Wydział Historyczno-Socjologiczny

Uniwersytet w Białymstoku

\title{
Peter Burke, Społeczna historia wiedzy, przeł. A. Kunicka, Wyd. Aletheia, Warszawa 2016, 656 stron
}

Niedawno, nakładem wydawnictwa Aletheia, ukazała się praca Społeczna historia wiedzy autorstwa historyka kultury i historii społecznej Petera Burke'a, profesora emeritus Emmanuel College (University of Cambridge). W książce podjęto próbę przedstawienia historii wiedzy wspartej, jak ujmuje to sam autor, teoriami „klasycznymi” Émila Durkheima, Maksa Webera, Michela Foucault i Pierre'a Bourdieu (s. 22). Do stworzenia tej syntezy P. Burke wykorzystał zebraną pieczołowicie bazę materiałową, którą udostępnia czytelnikowi w postaci załączonej bibliografii, zgromadzonej w imponującej liczbie (bibliografia zamieszczona na ostatnich 61 stronach pracy!). I tak na jej łamach odnaleźć można literaturę dostępną w języku angielskim, francuskim czy też niemieckim. Znalazły w niej swoje miejsce także prace polskich badaczy np. Krzysztofa Pomiana, Bronisława Malinowskiego, znane autorowi z przekładów na język francuski czy też angielski.

$\mathrm{W}$ wersji angielskiej została ona opublikowana w dwóch tomach. Pierwszy tom obejmuje czasy Od Gutenberga do Diderota (XVI-XVIII w.), skupiając się m.in. na instytucjonalizacji, kształtowaniu, organizacji i przemianach systemów nauczania, kształtowaniu sylwetki naukowca, zależności nauk od Kościoła i państwa, powstaniu prasy, odbiorcach. Tom drugi, podzielony na trzy części - Praktyki wiedzy, Cenę postępu i Społecznq historię w trzech wymiarach, dotyczy czasów Od Encyclopédie do Wikipedii (od XVIII w. do czasów najnowszych). Obejmuje on procesy, jakim poddana była wiedza, m.in. globalizacji, profesjonalizacji czy specjalizacji oraz próbując uchwycić geografię czy też socjologię wiedzy. Sam układ pracy jest uporządkowany, chociaż nie do końca chronologiczny (autor dokonuje retrospekcji i dzięki temu zabiegowi oba tomy uzyskują spójną strukturę).

Tematem studium jest szeroko pojęta historia wiedzy, której „Nie zbiera się (...) jak muszli na plaży, nie zrywa w postaci owoców z drzewa wiadomości ani nie chwyta jak motyli”. Sama definicja wiedzy będzie odnosiła się do tego „co myśl «ugotowała», przetworzyła lub usystematyzowała” (s. 23). 
Autor prezentuje zmieniające się na przestrzeni lat modele myślenia i uprawiania nauk. Cała narracja prowadzona jest w taki sposób, że czytelnik sam dostrzeże znane mu procesy dziejowe zachodzące w minionych wiekach. Samo słowo „wiedza" użyte zostało w pracy celowo w liczbie mnogiej - ,wiedze w liczbie mnogiej, tak jak opinie, są pożądane, ponieważ zrozumienie rodzi się z intelektualnego dialogu, a nawet konfliktu" (s. 267), aby w ten sposób podkreślić, iż wiedzy jako takiej nie da się zaszufladkować, a na przestrzeni dziejów zmieniało się podejście do tego, co w danym czasie za nią uchodziło. Ponadto P. Burke w przedstawieniu zróżnicowanego podejścia do świata wiedzy widzi swego rodzaju zadośćuczynienie szkód wyrządzonych specjalizacją, odejściem od wszechstronności na rzecz zawężania pola badawczego. Podkreśla, iż cechą charakterystyczną specjalizowania się w wąskim zakresie, a zarazem tego wadą, jest zjawisko posiadania przez ludzi nauki coraz mniejszej wiedzy na ograniczoną liczbę tematów. Wyraża przy tym nadzieję na poszerzenie świadomości współczesnych o ,systemie wiedzy”, w jakim dziś żyjemy poprzez opis i analizę przeszłości. Za główny cel książki P. Burke obrał swego rodzaju próbę ,precyzyjniejszego zdefiniowania specyfiki współczesności dzięki przyjrzeniu się jej w kontekście długotrwałych trendów" (s. 12).

A wszystko zaczęło się od druku... Według autora wynalazek ten stał się kamieniem milowym w rozwoju nauk i upowszechnianiu wiedzy. Ułatwił interakcje między różnymi jej dziedzinami. W pracy w klarowny sposób została ukazana ewolucja systemu nauczania, tworzenia nowych grup zawodowych (np. drukarze) i społecznych. Przedstawiono zmiany i mechanizmy, jakie zachodziły w tzw. kulturze zachodniej, w europejskim podejściu do wiedzy, w sposobie myślenia. Co więcej, P. Burke zastosował w swoim studium współczesne określenia, tj. „,brokerzy informacji” czy „menedżerowie wiedzy”, by opisać zjawiska występujące od oświecenia. Jednocześnie, co stanowi niewątpliwy atut pracy, ukazuje także drugą stronę medalu. Zwraca uwagę nie tylko na rozwój wiedzy, zmieniające się modele myślenia historycznego, ale i na dewaluację wiedzy uznanej za przestarzałą bądź też niepełną. Podkreśla jak poszerzanie wiedzy dostarczało odpowiedzi, ale także rodziło coraz to nowe wątpliwości.

Ponadto P. Burke, w jednym z rozdziałów, opisuje narodziny dyscyplin naukowych, niejako stanowiących sposób klasyfikacji poszczególnych wiedz, podkreślając tym samym, że „nauka Zachodu z luźnego zbioru lokalnych stowarzyszeń, instytutów badawczych i programów akademickich stała się ciągiem gęsto sprofesjonalizowanych dyscyplin, wysoce scentralizowanych w ramach państwa i często asekurowanych przez rząd i komercyjne wsparcie" (s. 572).

Omawiając poszczególne zagadnienia autor nie tylko odpowiada na postawione przez siebie pytania badawcze, ale unaocznia luki, które miałyby sprowokować uczonych do podjęcia badań w zakresie ich wypełnienia (np. historycy powinni przyjrzeć się muzeom w kontekście szerzenia przez nie wiedzy - gdyż „,przestrzeń mówi (...) za pośrednictwem aranżacji obiektów pewni ludzie przekazują 
wiadomości innym" (s. 370-371), czy pokusić się o opracowanie książkowe dotyczące uczonych w nowożytnej Europie (s. 46). Ponadto, ogromna erudycja autora, a co za tym idzie operowanie mnogością nazwisk, dzieł, dat oraz dobór odpowiednich przykładów, w połączeniu z lekkim piórem sprawia, że prezentowane studium jest przejrzyste, a odbiorca nie gubi się w „zalewie informacji”. W doskonały sposób ukazane zostały także analogie. Autor, mówiąc zarówno o XVI, jak i XXI w., unaocznia ponadczasowe problemy, np. podaż studentów od czasów wczesnonowożytnych przewyższa ich popyt czy też, występujące na przestrzeni wieków, problemy związane z finansowaniem prac badawczych.

Jednak, pomimo wyjątkowości tej pracy, czytelnika spotka kilka drobnych zaskoczeń. Jak zauważa P. Burke, Republika Wiedzy dokonała swego żywota najpóźniej w 1800 r. (s. 496-497). W tym momencie na myśl nasuwa się jedno pytanie: dlaczego autor tak twierdzi? Można przecież powiedzieć, że owa ,wyimaginowana społeczność" istnieje dzisiaj. Czyż uczeni z różnych krajów nie współpracują ze sobą, nie wymieniają informacji, listów (e-maili), nie wykorzystują Internetu, nie odwiedzają się, nie korzystają z najnowszych publikacji? Czy w dalszym ciągu, szczególnie w dzisiejszych czasach uczeni nie przekraczają narodowych granic?

Kolejne zaskoczenie stanowić może kilkakrotne przytaczanie Royal Society, jako przykładu novum w systemie organizacji nauki we wczesnonowożytnej Anglii, a mianowicie powstawanie towarzystw naukowych, wytwarzające z biegiem czasu struktury instytucjonalne, stanowiące alternatywę dla uniwersytetów - alternatywę polegającą na braku przynależności klasowej czy też majątkowej ich członków, których zakres badań nie ograniczał się do typowych przedmiotów akademickich wykładanych w tamtych czasach. Przed utworzeniem Towarzystwa Królewskiego mamy do czynienia z utworzeniem Elżbietańskiego Towarzystwa Antykwarycznego - w pracy P. Burke'a pojawia się o tym wydarzeniu niewielka wzmianka, pomimo tego, że właśnie w literaturze angielskiej pojawiły się takie prace jak: A History of the Society of Antiquaries Joan Evans, czy z nowszych publikacji In Defiance of Time. Antiquarian Writing in Early Modern England Augusta Vine'a traktujące o powstaniu, rozwoju i przemianach towarzystw naukowych w nowożytnej Anglii ${ }^{1}$. Ponadto, wydawać by się mogło, że pewien niedosyt wywołuje przywoływana przez autora zbyt mała ilość danych liczbowych, np. kiedy jest mowa o większej dostępności do książek czy bibliotek, archiwów (a co za tym idzie dostępu do materiałów źródłowych). Czy mamy ku temu dokładne dane? Jeżeli tak, to dlaczego nie zostały przytoczone? Kiedy mowa o cenach książek - w pierwszym tomie nie są podawane chociażby przybliżone kwoty. Dopiero

\footnotetext{
J. Evans, A History of the Society of Antiquaries, Oxford 1956; G. Parry, The Trophies of Time. English Antiquarians of the Seventeenth Century, Oxford 1995; M.S. Phillips, Reconsiderations on History and Antiquarianism: Arnaldo Momigliano and the Historiography of Eighteenth-Century Britain, "Journal of the History of Ideas" 1996, nr 57 (2), s. 297-316; A. Vine, In Defiance of Time. Antiquarian Writing in Early Modern England, Oxford 2010.
} 
w drugim tomie P. Burke podaje, że za dwa pensy można było nabyć tygodnik „Knowledge” (1881), a za cztery pensy tygodnik „Nature” (1869).

Zastanawiać może również brak pogłębionej refleksji ze strony autora. Poszczególne rozdziały, podrozdziały wręcz proszą o kilka zdań podsumowania. Burke jednak pozostaje niewzruszony i nie obdarza czytelnika chociażby krótkim komentarzem omawianych procesów, przechodząc do nowych wątków snutej opowieści. Być może jest to celowy zabieg dokonany ze strony autora, mający zachęcać czytelników do poszukiwania odpowiedzi i głębszego sensu w przywoływanych przez P. Burke przykładach?

Pragnę podzielić się także kilkoma uwagami dotyczącymi wydania pracy na gruncie polskim. Otóż, w polskiej edycji obydwa tomy połączono w całość, w przypadku wydania angielskiego tom pierwszy ukazał się drukiem w 2000 roku, kolejny zaś w roku 2012. Właściwsze wydaje się wydanie ich oddzielnie ewentualnie zamieszczenie, po każdym tomie, bibliografii, z której w danym momencie korzystał autor. Ponadto, w niektórych miejscach należałoby ujednolicić przekład, np. kiedy jest mowa o Karolu Marksie jego nazwisko w jednym miejscu zapisano „Marks” w drugim „Marx” (s. 179 i 348-349) oraz poprawienie błędnego zapisu „M15” i „M16” dotyczącego brytyjskich służb specjalnych na właściwy tj. „MI5” i „MI6” (s. 428; 576) oraz zastąpienie błędnego tłumaczenia określenia Kulturkampf jako „kampania kulturowa” (s. 563) na właściwy - ,walka o kulturę”. Zmienić także należałoby zapis, dotyczący tego jakoby Émile Durkheim „piastował katedrę edukacji” (s. 465) kiedy w rzeczywistości była to katedra socjologii, którą objął w 1895 roku.

Niech na zakończenie wolno mi będzie jeszcze raz podkreślić niedosyt, jaki pozostawia u czytelnika lektura prezentowanej pracy. Poruszone zostały w niej bardzo ważne zagadnienia, sam autor unaocznia luki, które mogą stanowić przyczynek do dalszych, pogłębionych badań, mając nadzieję, że zostaną one w przyszłości wypełnione. Warto również przytoczyć cytat z eseju Of Studies autorstwa Francisa Bacona: „Niektóre książki są do smakowania, inne do połknięcia, nieliczne zaś do przeżucia i strawienia" (s. 216). Niewątpliwie Społeczna historia wiedzy należy do ostatniego rodzaju. 